\title{
Measurements of polymerization temperature of light-hardened dental materials using a thermal camera
}

\author{
by M. Dąbrowski*, R. Dulski*, P. Zaborowski**, M. Aluchna** and P. Trzaskawka* \\ * Military University of Technology, Institute of Optoelectronics, ul. Gen. Sylwestra Kaliskiego 2, 00-908 Warsaw, \\ Poland \\ ** Central Military Surgery, ul. Koszykowa 78, 00-911 Warsaw, Poland
}

\section{Abstract}

The aim of the study was to evaluate the temperature rise of a new light-curing dental material Filtek Siloran during its polymerization. Measurements were made in vitro on laboratory stand using a thermal imaging system. The main task was to elaborate the thermal effects of extended light exposure time required for polymerisation of the new material. It was found that during the polymerization with two different lamps, the temperature increased to a level that is much higher than that for the traditional dental materials tested together for comparison with the new one.

\section{Introduction}

Basic materials used in dentistry are light-curing composite dental materials used for filling the tooth hard tissue defects. These materials are continuously improved in terms of their physical properties. Very important feature, from a clinical point of view, is polymerization shrinkage. It is highly undesirable because it influences durability of fillings and safety of tooth pulp, i.e., living pulp. It is essential in clinics treatment to have possibility of application and modelling of the material before the gelation point of its matrix is exceeded. It turned out that the used materials are sensitive to the light of operative lamps, ensuring indispensable comfort of a dentist work. This light causes premature initiation of a polymerization process.

New material Filtek Silorane, according to the producer assurance, has currently the lowest value of polymerization shrinkage and it is highly stable as well as resistant to the operative light. It is the first material devoted to direct fillings employing the epoxy resin in a polymerization reaction [1]. The producer does not publish too much details related to physical parameters of this material. A lot of them have not been measured yet, however, the works carried out for several years proved clinical usefulness of new materials and allowed for obtaining indispensable certificates.

The authors paid attention to the necessity of extension of the irradiation time, recommended by the producer, what is, so-called, "a cost" of comfort of work with the material of lower sensitivity to light. In the previous papers on estimation of temperature rise of light-curing materials, the authors showed relation between a kind of polymerization light, lamp radiation power, and a type of the cured material - resins content, and increase in the temperature during a polymerization process $[2,3,4,5]$. The suggested by the producer extension of irradiation time for a layer of new material of a thickness of $2.5 \mathrm{~mm}$ up to $40 \mathrm{~s}$, when the halogen lamp power does not exceed $1400 \mathrm{~mW} / \mathrm{cm} 2$, can be dangerous for the pulp especially because the tolerance threshold, taken for this sensitive tissue is a temperature increase of only $5^{\circ} \mathrm{C}$.

\section{Investigations}

The investigations were aimed at comparison of temperature changes of composite materials during their irradiation with polymerization lamps of various types and checking if the value of heat emitted during polymerization of a new material is not higher than the value admissible for patient health.

\subsection{Materials and measurements methodology}

For the investigation, the following composite materials were used: ValuxTM Plus, FiltekTM P60 and a new material - FiltekTM Siloran. The applied materials were produced by one producer (3M ESPE firm) and they have the same declared colour A3 what ensured comparable emission properties [6].

As a light source, also the lamps of 3M ESPE firm were used, i.e., Elipar Free Light halogen lamp and Elipar Free Light II diode lamp of the power, declared by the producer, of over $1000 \mathrm{~mW} / \mathrm{cm} 2$. The temperature changes on the surface of the being polymerized materials were registered by means of a thermal camera ThermaCAM P640 of FLIR Systems. The camera is equipped with uncooled matrix of FPA microbolometric detectors of the resolution of $640 \times 480$ pixels. Due to such high spatial resolution, the images registered by a camera are very detailed. The camera has a thermal resolution at the level of $60 \mathrm{mK}$, allowing for registration of the temperatures distribution with high precision reaching tenth of a degree. It operates in a spectral range from $7.5 \mu \mathrm{m}$ to $13 \mu \mathrm{m}$ and can be used for registration of single thermograms as well as for a sequence of images with a velocity of up to 30 images per second. The applied methodology of thermal measurements of the temperature was consistent with the procedure verified in the previous investigations [2,3,4,5]. The 2-mm diameter hole was made in a 2-mm thickness teflon plate which was fixed in a holder. This hole was filled with the tested materials. 
A sample was irradiated from one side of the plate and from the other side, the temperature changes were registered on its surface with a velocity of three images per second (Fig. 1).

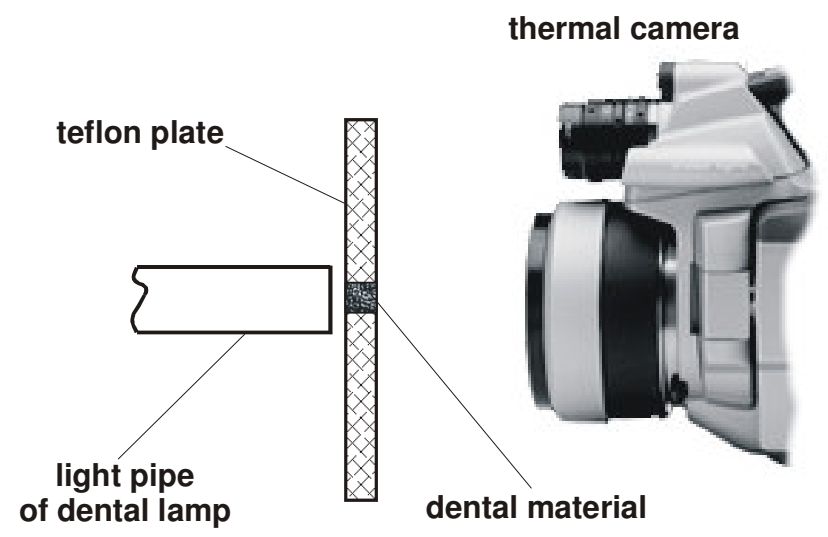

Fig. 1. Scheme of measurement performance

\subsection{Obtained results}

The measurement results were illustrated by means of the diagrams of temperature increase in curing material as a function of time. Figure 2 shows increase in maximum temperature on the surface of investigated materials that were cured by means of a halogen lamp.

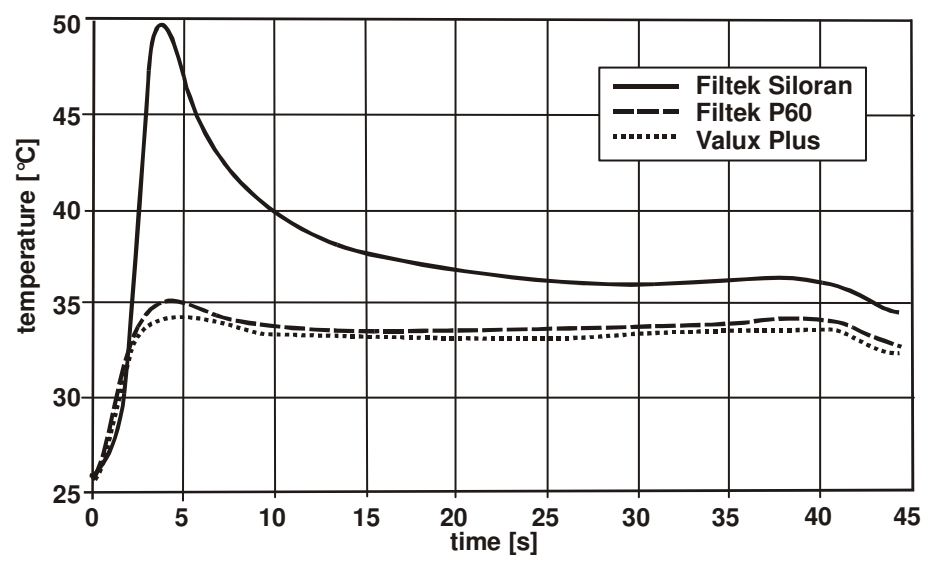

Fig. 2. Temperature increase in material during its polymerization obtained by means of a halogen lamp

The change of temperature for Filtek P60 and Valux Plus was comparable and maximum increase was of about $9^{\circ} \mathrm{C}$. For Filtek Siloran, this increase was significantly higher, i.e., of about $24^{\circ} \mathrm{C}$. Similar situation was observed when the above mentioned materials were cured using a diode lamp (Fig. 3). In this case, the temperature growths were higher due to the higher power of the applied lamp and were: $10^{\circ} \mathrm{C}$ for Filtek $\mathrm{P} 60,12^{\circ} \mathrm{C}$ for Valux Plus, and $32^{\circ} \mathrm{C}$ for Filtek Siloran. 


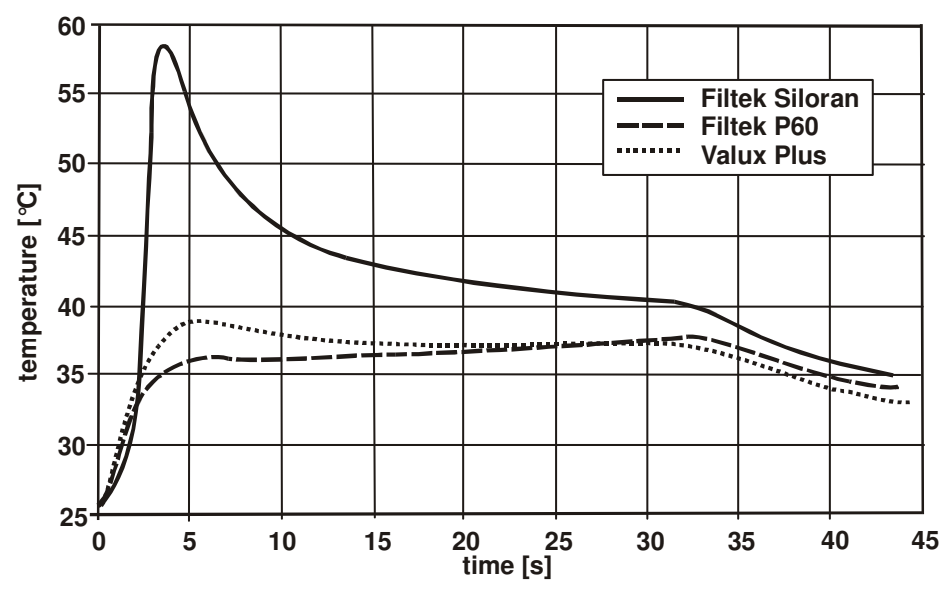

Fig. 3. Temperature increase in material during its polymerization obtained by means of a diode lamp

Independently of the used lamp, for Filtek P60 and Valux Plus, the temperature increases up to the maximum value during five seconds and next it is kept at similar level during the whole process of sample irradiation. Significant difference was observed for Filtek Siloran. The temperature increases up to the maximum value during three seconds, next its decreases of about $40 \%$ during seven seconds. In the following seconds, till the irradiation process end, the temperature decrease is not so dynamic.

\section{CONCLUSIONS}

In the known and commonly used materials, such as Valux and Filtek P60, made on the basis of acrylic resins, the temperature rises insignificantly during the polymerization and the threshold temperature of tooth pulp is not exceeded even during long lasting irradiation. New material Filtek Silorane, based on epoxy resins, shows significant temperature increase at the surface and maximum temperature value in this case considerably exceeds the tolerance threshold for tooth pulp. The observed, high increase in the epoxy materials temperature is for sure caused by entirely different course of a polymerization reaction.

It should be noticed that despite the obvious conclusions, drawn from the carried out investigations, the simultaneously performed clinical observations with Filek Silorane did not show negative reactions in teeth pulp, hypersensitivity after the treatment, and negative patients experience during the treatment. Thus, it seems to be purposeful to carry out further investigations, both on physical properties of a new material and on temperature increases during material polymerization under the conditions that are very close to in vivo ones. In the investigations, the effect of heat abstraction through the layer of a connective tissue should be considered. To achieve the above purpose, the authors are going to develop the investigations methodology that could much faithfully reproduce the thermal conditions that exist during the tooth defect filling in a patient's oral cavity.

\section{REFERENCES}

[1] Ilie N, Hickel R.: Silorane-based dental composite: behaviour and abilities. Dental Materials Journal, No 25(3), pp. 445-454, 2006.

[2] Żmuda S., Zaborowski P., Trykowski P., Dąbrowski M., Dulski R.: Wzrost temperatury na powierzchni zęba po naświetlaniu lampami polimeryzacyjnymi w warunkach in vitro i in vivo. (Temperature increase on a tooth surface after irradiation with polymerization lamps in vitro and in vivo) Stomatologia Współczesna (Contemporary Dentistry), vol. 5 No 4/98, pp. 259-264, 1998. (in Polish)

[3] Dabrowski M., Dulski R. Żmuda S., Zaborowski P.: Wpływ źródła światła lampy na wzrost temperatury materiałów dentystycznych w procesie polimeryzacji.

[4] (Influence of a lamp light source on temperature increase in dental materials during their polymerization), Magazyn Stomatologiczny, (Dentistry Magazine) Supplement No 4(116), pp. 72-74, 2001. (in Polish)

[5] Dabrowski M., Dulski R. Żmuda S., Zaborowski P., Pogorzeliski C.: A casebook of infrared imaging in clinical medicine-(praca zbiorowa-collective work) Thermal evaluation of the temperature distribution in the oral cavity during dental operations - the process of change in temperature distribution of tooth surface during dental material polymerization, Medpress, Warsaw, 2003.

[6] Dąbrowski M., Dulski R., Zaborowski P., Żmuda S.: Badanie efektów cieplnych w czasie polimeryzacji materiałów do wypełnień ubytków (Investigations of thermal effects during polymerization of materials used for defects filling). Pomiary Automatyka Kontrola (Measurements, Automation, Checking), No 9, pp. 44-47, 2006

[7] Żmuda S., Zaborowski P., Trykowski P., Dąbrowski M., Dulski R.: Wpływ własności emisyjnych materiałów dentystycznych i tkanek twardych zęba na bezkontaktowy pomiar temperatury uzębienia (Influence of emission properties of dental materials and tooth hard tissues on contactless measurement of teeth temperature). Stomatologia Współczesna (Contemporary Dentistry), Supplement No 1, pp. 8-12, 2000. 
http://dx.doi.org/10.21611/qirt.2008.15_06_12 